\title{
PemetaAn ASPIRASi Masyarakat TaMansari TerhadaP KeWaJiban Sosial UniSba
}

\section{THE MAPPING OF TAMANSARI COMMUNITY'S ASPIRATION TOWARD UNISBA SOCIAL OBLIGATION}

\author{
${ }^{1}$ Sri Hidayati Djoeffan, ${ }^{2}$ Chusharini Chamid, ${ }^{3}$ Chairiawaty, ${ }^{4}$ Kausar Rahman,${ }^{5}$ Vivy \\ Sofiah \\ 1,2,3,4,5 Fakultas Teknik Prodi Perencanaan Wilayah dan Kota Universitas Islam Bandung \\ e-mail:' ${ }^{1}$ hidayati_sri@yahoo.com,
}

\begin{abstract}
In the annual report of Rector of UNISBA, academic years of 2014/2015, delivered in 57th Anniversary of UNISBA, p. 48. One of the UNISBA programs proposed in 2015 is mapping the community's need toward the existence of UNISBA, especially the community around UNISBA. UNISBA as one of Islamic university is righteously concerned about the surrounding areas which have supported the life of the university and has been commonly known as the students village which has its own nuance, problems and potency. This study aims to find out the Aspirations of Kelurahan Taman Sari community on the existence of UNISBA with a focus on environmental issues covering $3 \mathrm{RW}$ directly adjacent to the UNISBA, namely $R W 13$ and $R W$ 14.This study is the first year study funded by LPPM UNISBA. By using the Field Survey and Participatory method, it is found that there are various potencies and problems including functional degradation, environment and visual as well as the public aspiration. The functional degradation was described by the violence of rule of river border. The degradation of environment was found in the bad quality of water, damp air, high density, and the poor public sphere, and lack of vegetation and wet land, as well as the puddle making the wore condition of the building. The visual degradation was viewed from the un convenient scenery, bad smell, and poor colour.Based on the problem and potential identification as well as the public aspiration it can be concluded several various research strategies and programs for the community services in the long term, mid term, and short term which can be followed up by Unisba Research Center and Community Services that can involve some faculties among Unisba.
\end{abstract}

Keywords : Area/Region, degradation, potential, problems and programs

\begin{abstract}
Abstrak. Dalam laporan tahunan Rektor UNISBA, tahun akademik 2014/2015, disampaikan pada HUT ke-57 dari UNISBA, p. 48. Salah satu program UNISBA yang diusulkan pada tahun 2015 adalah pemetaan kebutuhan masyarakat terhadap keberadaan UNISBA, terutama masyarakat sekitar UNISBA. UNISBA sebagai salah satu universitas Islam adalah selayaknya prihatin dengan daerah sekitarnya yang telah mendukung kehidupan universitas dan telah dikenal sebagai desa siswa yang memiliki nuansa tersendiri, masalah dan potensi. Penelitian ini bertujuan untuk mengetahui Aspirasi masyarakat Kelurahan Taman Sari pada keberadaan UNISBA dengan fokus pada isu-isu lingkungan yang meliputi $3 \mathrm{RW}$ berbatasan langsung dengan UNISBA, yaitu $R W 13$ dan $R W$ studi 14. Penelitian ini adalah studi tahun pertama yang didanai oleh LPPM UNISBA. Dengan menggunakan Survey Lapangan dan metode partisipatif, ditemukan bahwa ada berbagai potensi dan masalah termasuk degradasi fungsional, lingkungan dan visual serta aspirasi
\end{abstract}


masyarakat. Degradasi fungsional digambarkan oleh pengerasan aturan sempadan sungai. Degradasi lingkungan ditemukan dalam kualitas buruk air, udara lembab, kepadatan tinggi, dan ruang publik yang buruk, dan kurangnya vegetasi dan tanah basah, serta genangan air membuat mengenakan kondisi bangunan. Degradasi visual dilihat dari pemandangan yang tidak membuat nyaman, bau, dan kusam. Berdasarkan masalah dan identifikasi potensi serta aspirasi masyarakat dapat disimpulkan beberapa berbagai strategi penelitian dan program untuk layanan masyarakat dalam jangka panjang, jangka menengah, dan jangka pendek yang dapat ditindaklanjuti oleh LPPM Unisba yang dapat melibatkan beberapa fakultas di Unisba.

Kata Kunci: Area / Wilayah, degradasi, potensi, masalah dan program

\section{Latar Belakang}

Jumlah penduduk perkotaan saat ini sudah mencapai lebih dari 50\% dari total penduduk Indonesia. Pesatnya perkembangan penduduk perkotaan tersebut, yang umumnya berasal dari urbanisasi tidak selalu dapat diimbangi oleh kemampuan pelayanan kota sehingga telah berakibat pada semakin meluasnya perumahan dan permukiman kumuh. Permukiman kumuh merupakan masalah yang dihadapi oleh hampir kota-kota besar di Indonesia bahkan kota-kota besar di negara berkembang lainnya. Kajian tentang permukiman kumuh (slum), pada umumnya mencakup tiga segi, kondisi fisiknya, sosial ekonomi budaya komunitas yang bermukim di pemukiman tersebut, dan dampak oleh kedua kondisi tersebut. Kondisi fisik antara lain tampak dari bangunannya yang rapat dengan kualitas konstruksi rendah, jaringan jalan tidak berpola dan tidak diperkeras, sanitasi umum dan drainase tidak berfungsi serta sampah belum dikelola dengan baik.

Kondisi sosial ekonomi masyarakat yang berada di kawasan pemukiman kumuh antara lain mencakup tingkat pendapatan rendah, norma sosial yang longgar, budaya kemiskinan yang mewarnai kehidupannya yang tampak dari sikap dan perilaku yang apatis. Kondisi tersebut sering juga mengakibatkan kondisi kesehatan yang buruk, sumber pencemaran, sumber penyebaran penyakit dan perilaku menyimpang, yang berdampak pada kehidupan kota keseluruhannya. Oleh karena itu kawasan pemukiman kumuh dianggap sebagai penyakit kota yang harus diatasi. Pada Sidang Umum PBB, tahun 2000 tercapai kesepakatan tujuan pembangunan global yang tertuang dalam Millenium Development Goals (MDGs). Salah satu targetnya adalah peningkatan kualitas hidup 100 juta masyarakat dunia di perumahan dan permukiman kumuh pada tahun 2020. Selanjutnya, Kongres Perumahan dan Permukiman II yang dilaksanakan pada tanggal 18-19 Mei 2009 yang lalu juga menargetkan tercapainya kota tanpa permukiman kumuh tahun 2025 dalam Agenda Menyongsong Era Baru Perumahan dan Permukiman Indonesia.

Pemerintah Kota Bandung telah melakukan berbagai langkah terhadap permukiman kumuh, antara lain dengan Program Perbaikan Kampung (KIP), yang telah dilakukan sejak tahun 1978. Juga ada yang ditata dan dibangun kembali menjadi rumah susun seperti yang telah dilakukan terhadap permukiman kumuh di industri dalam. Ada pula yang dirangsang agar masyarakat memperbaikinya sendiri seperti misalnya yang 
dilakukan dengan program bantuan aspal, tetapi juga ada yang cenderung dibiarkan. Selain itu, dalam rangka proyek penataan Permukiman Kumuh di Bandung 1998 telah dilakukan kajian untuk mengklasifikasi kampung kumuh di Kota Bandung. Berdasarkan data permukiman kumuh perkotaan, Kota Bandung merupakan kota dengan jumlah lokasi permukiman kumuh terbanyak (367 lokasi) sebagai akibat dari keragaman aktivitas yang tersebar secara parsial. Hal ini menjadikan dasar Kota Bandung sebagai lokasi prioritas Penanganan Lingkungan Perumahan Dan Permukiman Kumuh Berbasis Kawasan (PLP2K-BK).

Kebutuhan akan rumah di kota Bandung atau backlog sebanyak : 21.172 Unit. Berdasarkan data tahun 2006 (Dinas Perumahan) terdapat 62 titik kawasan kumuh di kota Bandung, sebagaimana dapat dilihat pada tabel di bawah ini:

Tabel 1.1 Data Kawasan kumuh perkotaan di Indonesia Tahun 2011

\begin{tabular}{|l|c|c|c|c|c|}
\hline \multicolumn{1}{|c|}{ Kota } & $\begin{array}{c}\text { Jumlah lokasi } \\
\text { permukiman } \\
\text { kumuh }\end{array}$ & $\begin{array}{c}\text { Luas } \\
\text { permukiman } \\
\text { kumuh }\end{array}$ & $\begin{array}{c}\text { Luas } \\
\text { bangunan } \\
\text { di lokasi } \\
\text { kumuh }\end{array}$ & $\begin{array}{c}\text { Jumlah } \\
\text { KK di } \\
\text { lokasi } \\
\text { kumuh }\end{array}$ & $\begin{array}{c}\text { Luas } \\
\text { penduduk di } \\
\text { lokasi kumuh }\end{array}$ \\
\hline Bandung & 367 & 202 & 26,264 & 30,281 & 121,124 \\
\hline Denpasar & 36 & 24 & 943 & 1,258 & 5,032 \\
\hline Jakarta barat & 636 & 449 & 20,498 & 36,518 & 148,168 \\
\hline Jakarta pusat & 446 & 169 & 10,505 & 23,162 & 90,464 \\
\hline $\begin{array}{l}\text { Jakarta } \\
\text { selatan }\end{array}$ & 325 & 277 & 19,748 & 18,658 & 73,228 \\
\hline Jakarta timur & 339 & 282 & 22,184 & 25,162 & 93,345 \\
\hline Jakarta utara & 531 & 407 & 31,879 & 42,084 & 165,142 \\
\hline Makassar & 285 & 323 & 11,629 & 17,278 & 69,112 \\
\hline Medan & 165 & 31 & 14,101 & 15,927 & 63,708 \\
\hline Palembang & 367 & 15 & 14,243 & 20,928 & 83,712 \\
\hline Semarang & 133 & 40 & 7,365 & 8,239 & 32,956 \\
\hline Surabaya & 141 & 59 & 6,158 & 6,958 & 27,832 \\
\hline
\end{tabular}

Sumber : Sistem infornasi kawasan kumuh perkotaan, 2011

Saat kini kegiatan peneitian dan PKM Unisba diarahkan pada tema Humaniora dan rekayasa induatri. Hal ini berdasarkan rencana kegiatan LPPM Unisba yang diantaranya Pengembangan kemamuan mengadaptasi pengetahuan dan teknologi unutk kebutuhan pembangunan daerah (terutam di wilayah Jawa Barat dan sekitarnya) dan nasional ( Laporan Tahunan Rektor Universitas Islam Bandung, Tahun Akademik 2014/2015), Milad 57, hal.48.Salah satu program Unisba yang telah dicanangkan pada tahun 2015 adalah memetakan kebutuhan masyarakat terhadap keberadaan Unisba, terutama masyarakat sekitar Unisba. Berdasarkan informasi di atas, Kawasan Tamansari merupakan kawasan yang berdekatan langsung dengan Unisba yang sarat dengan berbagai permasalahan merupakan obyek penelitian yang sinkron dengan Renstra PKM Unisba dan sudah saatnya Unisba peduli dan memberikan kontribusi terhadap perkembangan wilayah yang sangat menunjang hidupnya kampus, dimana kawasan berfungsi sebagai permukiman mahasiswa yang melakukan studi di Unisba. 


\subsection{Permasalahan}

Unisba sampai saat kini masih belum menunjukan suatu jalinan kerjasama formal dalam bersinergi membina lingkungan yang harmonis dengan lingkungan sekitarnya yakni kawasan Tamansari. Sebagai suatu lembga pendidikan Islam sudah saatnya memeliki rencana dan tindak di lapangan yang dapat dilakukan oleh seluruh civitas akademika fakultas yang ada dalam lingkungan kampus Unisba. Sehingga kelak Unisba memiliki kamanfaatan bagi terealisasinya Hablu Minanas dan hablu Minallah.

\section{$1.2 \quad$ Urgensi}

Urgensi dari peneitian ini Unisba dapat mengetahui dan memetakan aspirasi masyarakat Tamansari yang membutuhkan intervensi Unisba melalui penjaringan aspirasi masyarakat. Sehingga akan terumuskan permasalahan dan potensi kawasan , kebutuhan dan keinginan masyarakat yang kalak akan di rumuskan dalam program penelitian dan pengabdian seluruh Fakultas yang berada di dalam naungan Unisba (PKM Unisba).

\subsection{Ruang Lingkup wilayah penelitian.}

Ruang lingkup wilayah penelitian meliputi satu kelurahan Tamansari.

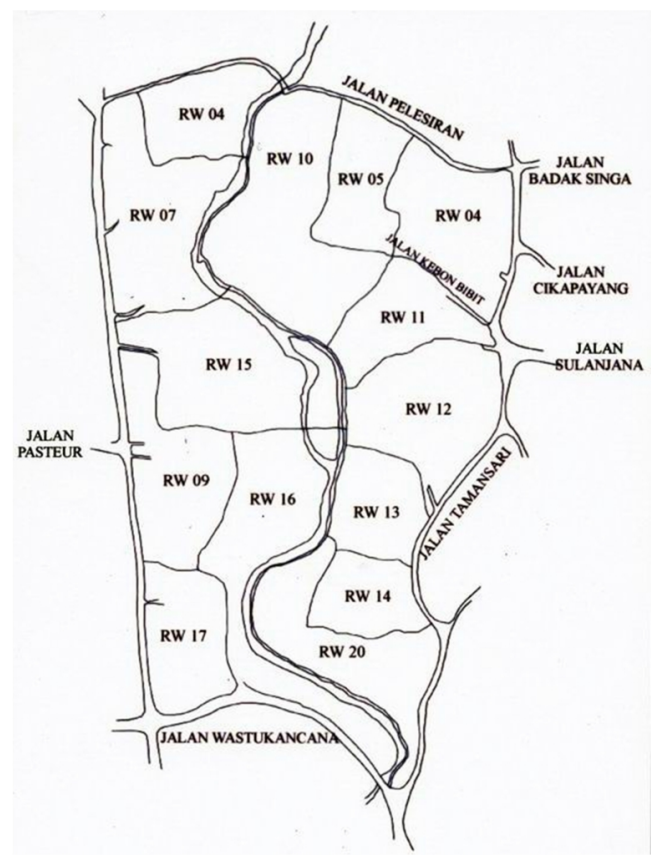

Gambar 1.1. Daerah Administrasi Penelitian

\subsection{Tujuan}

Tujuan penelitian tentang "Pemetaan Aspirasi Masyarakat Tamansari Terhadap Kewajiban Sosial Unisba" adalah untuk memetakan aspirasi masyarakat Tamansari yang membutuhkan intervensi Unisba. Sedangkan sasaran kegiatan 
penelitian, antara lain adalah teridentifikasinya permasalahan dan potensi kawasan , kebutuhan dan keinginan masyarakat.

\subsection{Manfaat Penelitian}

Manfaat Penelitian adalah sebagai berikut:

1. Adanya relasi yang harmonis antara Unisba dengan masyarakat yang perlu dikembangkan serta penyusunan program kerja penelitian masa datang.

2. Terciptanya Program Kerja Penelitian dan pengabdian di LPPM Unisba yang sesuai dengan kebutuhan masyarakat sekitasr Unisba.

3. Terjalinnya kerjasama dengan pihak swasta dalam menyalurkan sebagian dana CSR d erusahaan mereka yang tebih nyata.

\subsection{Luaran Penelitian.}

1. Dapat dipublikasikan dalam Seminar Nasional.

2. Dapat digunakan sebagai kekayaan bahan ajar.

3. Dapat menciptakan penelitian dan pengabdian lanjutan

\section{Tinjauan Pustaka}

\subsection{Road Map Penelitian}

Saat kini kegiatan peneitian dan PKM Unisba diarahkan pada tema Humaniora dan rekayasa induatri. Hal ini berdasarkan rencana kegiatan LPPM Unisba yang diantaranya Pengembangan kemamuan mengadaptasi pengetahuan dan teknologi unutk kebutuhan pembangunan daerah (terutam di wilayah Jawa Barat dan sekitarnya) dan nasional ( Laporan Tahunan Rektor Universitas Islam bandung, Tahun Akademik 2014/2015), Milad 57, hal.48, yang mana salah satu program Unisba yang telah dicanangkan pada tahun 2015 adalah memetakan kebutuhan masyarakat terhadap keberadaan Unisba, terutama masyarakat sekitar Unisba.

Partisipasi masyarakat sebagai upaya untuk memberdayakan masyarakat, harus dilakuan sebuah terobosan agar masyarakat dibangkitkan kesadarannya bahwa ada kehidupan yang lebih baik dari sekarang ,bahwa ada harapan serta peluang untuk memperbaiki kehidupan. Akab tetapi untuk melakukannya harus ada usaha dari sendiri, yang menyangkut masalah mental, pengetahuan kecakapan dan juga kesejahteraan sember daya manusianya.

Peran partisipasi masayakat dalam pembangunan yang diawali oleh perencanaan tata ruang yang menliputi perencanaan, pelaksanaan dan pengawasan serta pengendalian telah dilakukan oleh peneliti sejak tahun 1990 sampai 2015 dengan peta penelitian sebagai berikut : 
Tabel 2.1 Road map Penelitian

\begin{tabular}{|c|c|c|}
\hline Perioda Peneliti & Judul Penelitian & Keterangan \\
\hline \multirow[t]{5}{*}{$\begin{array}{l}\text { Tahun } 1990 \mathrm{~s} / \mathrm{d} \\
2000\end{array}$} & $\begin{array}{l}\text { Rencana Tata Letak Lingkungan } \\
\text { perumahan RW } 20 \text { Kelurahan Tamansari } \\
\text { Bandung (1991) }\end{array}$ & Kegiatan Studio Perencanaan Tapak \\
\hline & $\begin{array}{l}\text { Jalan Layang Paspati Sebagai Suatu } \\
\text { Momentum Peremajaan Kota di Kawasan } \\
\text { Tamansari Bandung (2001). }\end{array}$ & $\begin{array}{l}\text { Jurnal Perencanaan Wilayah dan Kota } \\
\text { ITB. ISSN : - } 9847 . \\
\text { Vol.12. No.1 }\end{array}$ \\
\hline & $\begin{array}{l}\text { Penelitian dan Pengabdian Pada } \\
\text { Masyarakat tentang Pengelolaan } \\
\text { sampah/limbah Rumah Tangga di daerah } \\
\text { pemukiman Cigadung DT II (1993) } \\
\text { Kodya Bandung. }\end{array}$ & $\begin{array}{l}\text { Disosialisasikan di masyarakat } \\
\text { kompleks Dosen Unpad Cigadung }\end{array}$ \\
\hline & $\begin{array}{lrr}\text { Rencana } & \text { Teknis } & \text { Pengembangan } \\
\text { desa Adat sebagai obyek wisata } & \text { Budaya } \\
\text { Indonesia } & \text { di Propinsi Sumatra Barat dan } \\
\text { Jambi. } & \text { Bertindak } & \text { selaku } \\
\text { Planner/Planolog. (1999). } & \\
\end{array}$ & $\begin{array}{lrr}\text { Penyusunan } & \text { Program } & \text { Pariwisata di } \\
\text { Sumbar dan Jambi } & \text { (Kementrian } \\
\text { Pariwisata) } & & \\
\end{array}$ \\
\hline & $\begin{array}{l}\text { Peremajaan kawasan Berkepadatan } \\
\text { Tinggi di kawasan Tamansari Bandung } \\
\text { (1999) merupakan }\end{array}$ & Thesis Program S2 di Arsitektur ITB \\
\hline \multirow[t]{5}{*}{$\begin{array}{l}\text { Perioda } \\
2001-2005\end{array}$} & $\begin{array}{l}\text { Profil Prasarana Kawasan Pendidikan } \\
\text { Lembah Cikapundung } 2002\end{array}$ & $\begin{array}{l}\text { Telah diterbitkan dalam Jurnal Ethos } \\
\text { Unisba }\end{array}$ \\
\hline & $\begin{array}{l}\text { Strategi Partisipasi Masyarakat dalam } \\
\text { Perencanaan Pembangunan }\end{array}$ & $\begin{array}{l}\text { Jurnal Sosial dan Pembangunan , } \\
\text { "MIMBAR" UNISBA } \\
\text { ISSN 0215-8175. No.1 th.XVIII }\end{array}$ \\
\hline & $\begin{array}{l}\text { Inventasrisasi Sarana dan Prasarana } \\
\text { Permukiman di Lembah Cikapundung- } \\
\text { Tamansari Bandung. }\end{array}$ & $\begin{array}{l}\text { Jurnal Penelitian dan Pengabdian, Edisi } \\
\text { Teknik "Ethos" UNISBA. } \\
\text { Vol.1 No.2 }\end{array}$ \\
\hline & $\begin{array}{l}\text { 1. Evaluasi Perencanaan Rencana } \\
\text { DetaiL kota Ciwidey (2004) }\end{array}$ & $\begin{array}{l}\text { Telah dijadikan panduan pembangunan } \\
\text { Kota Ciwidey (Kimpraswil } \\
\text { Kab.Bandung). }\end{array}$ \\
\hline & $\begin{array}{lrr}\text { Ruang } & \text { Pertahanan Sebagai } & \text { Suatu } \\
\text { Paradigma } & \text { Perancangan } & \text { Kota } \\
\text { Berwawasan Lingkungan dengan } & \text { studi } \\
\text { kasus kelurahan Tamansari Bandung. } & \text { Band } \\
(2005) & & \\
\end{array}$ & $\begin{array}{l}\text { Jurnal ITENAS } \\
\text { ISSN : } 1410-3125 . \\
\text { No.2 Vol..6 }\end{array}$ \\
\hline \multirow[t]{5}{*}{$\begin{array}{l}\text { Perioda } 2006- \\
2010\end{array}$} & $\begin{array}{llll}\begin{array}{l}\text { Profil kawasan } \\
(2006)\end{array} & & & \\
(2 a m a n s a r i & \text { Bandung } \\
\end{array}$ & Diterbitkan dalam Jurna Ethos Unisba. \\
\hline & $\begin{array}{l}\text { Rencana Detail Tata Ruang Kota Ujung } \\
\text { Berung (2006 - 2011) pada tahun } 2006\end{array}$ & $\begin{array}{llr}\text { Diaplikasikan } & \text { sebagai } & \text { pedoman } \\
\text { pembangunan } & \text { Kecamatan } & \text { Ujung } \\
\text { Berung. } & & \\
\end{array}$ \\
\hline & $\begin{array}{lrr}\text { Ruang } & \text { Pertahanan Sebagai } & \text { Suatu } \\
\text { Paradigma } & \text { Perancangan } & \text { Kota } \\
\text { Berwawasan Lingkungan dengan studi } \\
\text { kasus kelurahan Tamansari Bandung. } \\
(2005) \text {. }\end{array}$ & \\
\hline & $\begin{array}{l}\text { Rencana Detail Tata Ruang kota Ciwidey } \\
(2005-2010)\end{array}$ & $\begin{array}{l}\text { Pedoman Pembangunan Kota Ciwidey } \\
(2005)\end{array}$ \\
\hline & Profil kawasan Tamansari Bandung & LPPM UNISBA \\
\hline
\end{tabular}




\begin{tabular}{|c|c|c|}
\hline & $(2006)$ & \\
\hline & $\begin{array}{l}\text { Rencana Detail Tata Ruang Kota Ujung } \\
\text { Berung }(2006-2011)-\text { tahun } 2006\end{array}$ & $\begin{array}{l}\text { Pedoman Pembangunan Kota Ujung } \\
\text { Berung (2005) }\end{array}$ \\
\hline & $\begin{array}{l}\text { Rencana Detail Tata Ruang Kota } \\
\text { Wilayah Karees Kodya bandung (2007 - } \\
\text { 2013) tahun } 2007\end{array}$ & $\begin{array}{l}\text { Pedoman Pembangunan Wilayah Karees } \\
\text { Kodya Bandung (2005) }\end{array}$ \\
\hline & 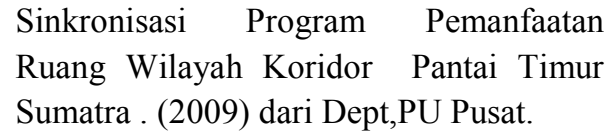 & $\begin{array}{lll}\text { Sumber } \quad \text { Penyusunan } & \text { Program } \\
\text { Pembangunan BAPPENAS. } & \end{array}$ \\
\hline & $\begin{array}{l}\text { Petunjuk Teknis Pengelolaan Dan } \\
\text { Pemantauan Lingkungan Hidup Kegiatan } \\
\text { Pengoperasian Dan Penghunian } \\
\text { Perumahan Tidak Bersusun (2009) }\end{array}$ & $\begin{array}{l}\text { Sebagai Draft Pedoman Mentri } \\
\text { perumahan . }\end{array}$ \\
\hline & $\begin{array}{l}\text { Strategi Pengelolaan Kawasan Wisata } \\
\text { Cagar Budaya Ciungwanara Karang } \\
\text { Kamulyan Sebagai Daerah Tujuan Wisata } \\
\text { di Kabupaten Ciamis. (2009) }\end{array}$ & $\begin{array}{l}\text { Surat Perjanjian Hibah } \text { Bersaing } \\
\text { Pelaksanaan Penelitian No. 70/B- } \\
\text { 5/LPPM-SP3?II/2009 an diterbitkan } \\
\text { dalam Proceeding SNAPP. }\end{array}$ \\
\hline & $\begin{array}{l}\text { Pedoman Penyelenggaraan Rumah Sewa } \\
\text { Tidak Bersusun di Perkotaan. (2009) }\end{array}$ & $\begin{array}{l}\text { Sebagai Draft Pedoman Mentri } \\
\text { perumahan. }\end{array}$ \\
\hline & $\begin{array}{l}\text { Strategi Pengembangan Perkotaan di } \\
\text { Pantai Timur Sumatra.(2009) }\end{array}$ & $\begin{array}{l}\text { Diterbitkan dalam Jurnal Mimbar } \\
\text { Unisba. 2009 }\end{array}$ \\
\hline $\begin{array}{l}\text { Perioda } 2011 \\
2015\end{array}$ & $\begin{array}{l}\text { Kelayakan produksi usaha Produksi } \\
\text { Kompos Limbah teh di Coca Cola Amatil } \\
\text { Indonesia (CCAI) Bandung. (2011). }\end{array}$ & $\begin{array}{l}\text { Diterbitkan dalam Proceeding SNAPP } \\
2011\end{array}$ \\
\hline & $\begin{array}{l}\text { Pelaksanaan Pekerjaan Rencana Rinci } \\
\text { Penanganan Lingkungan Perumahan dan } \\
\text { Permukiman di kawasan Tamansari - } \\
\text { Kemenpera } 2011\end{array}$ & $\begin{array}{l}\text { Pedoman pelaksanaan pembangunan } \\
\text { kawasan Balubur. }\end{array}$ \\
\hline & $\begin{array}{llr}\text { Pengaruh perkembangan High } & \text { Rise } \\
\text { Building terhadap Transportasi } & \text { dan } \\
\text { lingkugan }(2014 \text { dan 2015). } & \end{array}$ & \\
\hline
\end{tabular}

Berdasarkan uraian dan penjelasan tersebut di atas, tim peneliti telah sepakat bahwa penelitian berbasis partisipasi sangat urgent dilakukan dalam menjaring potensi dan aspirasi masyarakat dalam merumuskan berbagai program yang dapat disusun dan disinergikan dengan potensi Unisba.

\subsection{State of The Art}

\subsubsection{Pengertian Partisipasi}

Keterlibatan partisipasi masyarakat dalam pembangunan yang dianggap dapat mengatasi kesenjangan pembangunan yang terjadi. Hall i i telah diatur dalam UU No. 32 Tahun 2004 mengenai pemerintahan daerah disebutkan bahwa desa atau dengan nama lain, selanjutnya disebutkan kelurahan adalah kesatuan masyarakat hukum yang memiliki batas-batas wilayah yang berwenang untuk mengatur dan mengurus kepentingan masyarakat setempat, berdasarkan peraturan-peraturan yang berlaku dan adat istiadat setempat Partisipasi Masyarakat Dalam Pembangunan (Stepanus Henryk) diakui dan dihormati dalam sistem pemerintahan Negara Kesatuan Republik Indonesia. Tetapi terkadang tujuan yang ingin dicapai oleh pemerintah daerah khususnya, tidak 
seiring sejalan dengan tujuan yang ingin dicapai oleh masyarakat. Kerangka Dasar Teori Partisipasi Konsep partisipasi mencakup kerjasama antara semua unsur terkait dan merupakan suatu kesepakatan, harapan, persepsi dan sistem komunikasi dimana kemampuan dan pendidikan mempengaruhi sikap dan cara berprilaku seseorang. Partisipasi i berarti ambil bagian dalam suatu tahap atau lebih dari suatu proses). Proses yang dimaksud dalam tulisan ini tentu saja proses pembangunan.

Presiden Suharto sejak tahun 1966 menerapkan konsep partisipasi masyarakat dalam program pembangunan dan sesuai dengan paradigma pemerintahan orde baru yang sentralistik, seluruh kebijakan pembangunan dilakukan secara "top-down". Inisiatif dalam menetapkan kebijakan pembangunan berasal dari atas (pejabat berwenang) tanpa melibatkan masyarakat dan stakeholder lainnya. Dalam kaitan ini masyarakat dilibatkan dalam pelaksanaan kegiatan terutama dalam membantu dana maupun tenaga. Pada saat itu partisipasi dipandang sebagai proses mobilisasi yaitu penggerakkan masyarakat dalam kegiatan pembangunan. Meskipun model ini memiliki keunggulan karena pelaksanaan pembangunan dapat dilakukan secara cepat, namun kelemahan yang dijumpai adalah masyarakat sering merasa tidak memiliki dan tidak merasakan manfaat dari kegiatan pembangunan itu. Di era reformasi, partisipasi diberi makna sebagai keterlibatan masyarakat dalam proses politik yang seluas-luasnya baik dalam proses pengambilan keputusan dan monitoring kebijakan yang dapat mempengaruhi kehidupan mereka.

Menurut T.B. Simatupang dalam Khairuddin (2000: 124) memberikan beberapa rincian tentang partisipasi (eJournal Ilmu Pemerintahan, 2013, 1 (2): 612 - 625 ISSN 0000-0000, ejournal.ip.fisip-unmul.ac.id (C) Copyright 2013) sebagai berikut :

1. Partisipasi berarti apa yang kita jalankan adalah bagian dari usaha bersama yang dijalankan bahu membahu dengan saudara kita sebangsa dan setanah air untuk membangun masa depan bersama.

2. Partisipasi berarti pula sebagai kerja untuk mencapai tujuan bersama diantara semua warga negara yang mempunyai latar belakang kepercayaan yang beraneka ragam dalam negara Pancasila kita, atau dasar hak dan kewajiban yang sama untuk memberikan sumbangan demi terbinanya masa depan yang baru dari bangsa kita.

3. Partisipasi tidak hanya berarti mengambil bagian dalam pelaksanaanpelaksanaan rencana pembangunan. Partisipasi berarti memberikan sumbangan agar dalam pengertian kita mengenai pembangunan itu, nilai-nilai kemanusiaan dan cita-cita mengenai keadilan sosial tetap dijunjung tinggi.

\subsubsection{Peran partisipasi}

Partisipasi dalam pembangunan berarti mendorong ke arah pembangunan yang serasi dengan martabat manusia. Keadilan sosial dan keadilan nasional dan yang memelihara alam sebagai lingkungan hidup manusia, juga untuk generasi-generasi yang akan dating.Pembangunan Pengertian pembangunan disini diartikan sebagai suatu "proses" pembangunan sebagai proses menggambarkan adanya pengembangan, baik meliputi proses pertumbuhan (growth) ataupun perubahan (change) dalam kehidupan 
bersama (organisasi) sosial dan budaya. Hal ini merupakan gambaran umum masyarakat luas (society). Menelaah pembangunan dalam masyarakat adalah hal yang baru dalam sejarah. Menurut Inayatullah (dalam Agus Suryono, 2001: 1), pembangunan adalah perubahan menuju pola-pola masyarakat yang memungkinkan realisasi yang lebih baik dari nilai-nilai kemanusiaan yang memungkinkan suatu masyarakat mempunyai control yang lebih besar terhadap lingkungannya dan terhadap tujuan politiknya, dan yang memungkinkan warganya memperoleh control yang lebih terhadap diri mereka sendiri. Menurut Kleinjans yang dikutip dalam Agus Suryono (2001: 30) pembangunan adalah bukanlah sosial teknologi atau GNP, tetapi pencapaian pengetahuan dan keterampilan baru, tumbuhnya suatu kesadaran baru, perluasan Partisipasi Masyarakat Dalam Pembangunan (Stepanus Henryk) 615 wawasan manusia, meningkatnya semangat kemanusian, dan suntikan kepercayaan diri. Menurut Rogers dan Shoemaker (dalam Agus Suryono, 2001: 30), pembangunan adalah suatu jenis perubahan sosial dimana ide-ide baru perkapita dan tingkat kehidupan yang lebih tinggi melalui metode produksi yang lebih modern dan organisasi sosial yang lebih baik.

Pembangunan adalah modernisasi pada tingkat sistem sosial. Menurut Teguh Yuwono (2001: 47) mengatakan bahwa "pembangunan sosial yang besar dari suatu keadaan tertentu keadaan yang dipandang lebih bernilai. Pada umumnya tujuan-tujuan pembangunan adalah pembinaan bangsa atau perkembangan sosial ekonomi”. Konsep pembangunan menurut Rogers sendiri dalam Agus Suryono (2001: 132), pembangunan adalah suatu proses perubahan sosial dengan partisipatori yang luas dalam suatu masyarakat yang dimaksudkan untuk kemajuan sosial dan material (termasuk bertambah besarnya keadilan, kebebasan dan kualitas lainnya yang dihargai) untuk mayoritas rakyat melalui kontrol yang lebih besar yang mereka peroleh terhadap lingkungan mereka. Selanjutnya Patton (2005: 64-65), pembangunan meliputi beberapa pengertian antara lain :

1. Pembangunan itu harus merupakan suatu proses, ini dimaksudkan bahwa setiap usaha pembangunan pasti memerlukan kesinambungan pelaksanaan, dalam arti tanpa mengenai batas akhir meskipun dalam pelaksanaan perencanaannya dapat diluar berdasarkan atas skala prioritas dan tahapan-tahapan tertentu.

2. Pembangunan itu harus merupakan usaha-usaha yang dilakukan secara sadar, artinya tiap usaha pembangunan harus dilandasi dengan motivasai dasar, sasaran dan tujuan yang jelas dan rasional, atau dengan kata lain tidak hanya berdasarkan pemikiran-pemikiran emosional. Pembangunan harus dilakukan secara teratur, dalam arti harus berencana dan berorientasi pada pertumbuhan dan perubahan.

3. Pembangunan itu baik dalam perencanaan maupun dalam pelaksanaannya, harus sedemikian rupa mengarah ke modernitas, artinya harus membuahkan suatu perubaan dan hasil bagi masyarakat luas yaitu suatu bentuk cara hidup yang lebih baik dan lebih sejahtera dari keadaan sebelumnya, termasuk prospek pengembangan potensi dan sumber kehidupan di masa depan.

4. Sifat dan watak modernisasi yang akan dicapai itu harus sedemikian bercirikan multi dimensional, artinya harus mencakup semua aspek kehidupan. Pada 
akhirnya harus ada kesadaran, bahwa semua hal yang telah disebut diatas semata-mata ditentukan demi usaha pembinaan bangsa dan negara serta masyarakat pada umumnya sesuai dengan apa yang direncanakan sebelumnya. eJournal Ilmu Pemerintahan, Volume 1, Nomor 2 , 2013: 612 - 625616 Perencanaan Pembangunan Menurut Undang-undang No. 25 tahun 2004 tentang Sistem Perencanaan Pembangunan Nasional, perencanaan adalah suatu proses untuk menentukan tindakan masa depan yang tepat melalui urutan pilihan, dengan memperhatikan sumber daya yang ada. Pada dasarnya perencanaan digunakan agar kegiatan pembangunan dalam rangka pencapaian tujuan nasional dapat berjalan secara sistematis dan terarah.

\section{Metodologi Penelitian}

Penelitian ini akan dilakukan dengan metode survey melalui kuesioner dan wawancara. Beberapa pendekatan yang akan dilakukan untuk membangun kuesioner dan materi wawancara adalah sbb:

1. Pendekatan Normatif

Pendekatan ini menekankan pada kajian terhadap produk peraturan dan kebijakan Unisba terkait dengan rencana tanggung jawab sosial Unisba kepada masyarakat di sekitar Kampus Unisba. Melalui kajian ini akan diperoleh kebijakan dan strategi yang tepat untuk melaksanakan kegiatan sosial unisba kepada masyarakat Tamansari.

2. Pendekatan Komprehensif

Pendekatan ini adalah upaya mengumpulkan data dari beberapa aspek kehidupan seperti aspek ekonomi, sosial dan budaya masyarakat Tamansari. Beberapa penelitian yang telah dilakukan sebelumnya menjadi latar belakang informasi kondisi ekonomi, sosial dan budaya masyarakat Tamansari yang akan dikembangkan dalam penyusunan kuesioner dan materi wawancara.

3. Pendekatan Pembangunan Berkelanjutan

Pendekatan ini didasarkan pada konsep pembangunan berkelanjutan Unisba sebagai salah satu PTS di Kota Bandung. Unisba tentunya harus mempunyai rencana pengembangan sosial masyarakat, terutama untuk masyarakat di Tamansari.

4. Pendekatan Partisipatif

Pendekatan ini bertujuan untuk menjaring aspirasi masyarakat untuk menyusun rencana tanggung jawab sosial Unisba, sehingga kegiatan tanggung jawab sosial yang akan disusun tersebut menjadi tepat sasaran dan memiliki manfaat yang berdayaguna bagi masyarakat atau sesuai dengan kebutuhan masyarakat Tamansari.

\section{Hasil dan Pembahasan}

Hasil Penelitian meliputi gambaran umum kawasan penelitian, aspirasi masyarakat, kemudian potensi serta permasalahan kawasan sebagai rangkuman dari 
gambatran umum dan aspirasi masyarakat yang telah dihimpun. Gambaran umum kawasan penelitian terdiri dari 2 RW yakni RW 13 dan 14. Pada awal penelitian direncanakan RW20 juga menjadi objek penelitian, namun warga RW20 menyatakan menolak untuk diwawancarai, sehingga penelitian ini hanya dilakukan di RW13 dan RW14 saja. Gambaran umum kawasan penelitian dijelaskan pada sub bab berikut ini.

\subsection{Kepemilikan Lahan}

Mayoritas status kepemilikan lahan adalah milik pribadi warga, bahkan di RW14 kepemilikan lahan adalah 100\% milik pribadi, sedangkan di RW13 97\% milik pribadi dan hanya 3\% yang merupakan milik Pemerintah Kota Bandung. Status tanah yang dimiliki warga ternyata merupakan tanah bersertifikat seluruhnya, sehingga 100\% warga di RW13 dan RW14 telah memiliki sertfikat atas lahan yang mereka tempati.

\subsection{Kependudukan}

Jumlah penduduk di RW 13 dan 14 adalah 2.141 jiwa dengan kepadatan penduduk rata-rata 686 jiwa/Ha. $65 \%$ merupakan usia produktif yang berkisar antara 15 sapai 54 tahun. Kelompok usia anak (0-14 tahun) adalah 21\% dan usia manula (55 tahun lebih) sebanyak 14\%. Terlihat bahwa kelompok usia tergantungan, anak-anak dan manula, hanya $35 \%$, sehingan kira-kira hanya $50 \%$ dari usia produktif. Bila ditinjau dari lama tinggal, maka warga masyarakat RW 13 dan 14 Kelurahan Tamansari merupakan penduduk asli yang sudah lama menetap di daerah tersebut, lama menetap mayoritas lebih dari 10 tahun.

\section{Tabel 4.1 Jumlah dan kepadatan penduduk RW 13 dan 14 Kelurahan Tamansari} Bandung

\begin{tabular}{|c|l|c|c|c|}
\hline No & RW & $\begin{array}{c}\text { Jumlah penduduk } \\
\text { (jiwa) }\end{array}$ & $\begin{array}{c}\text { Luas } \\
\text { (Ha) }\end{array}$ & $\begin{array}{c}\text { Kepadatan penduduk } \\
\text { Jiwa/Ha }\end{array}$ \\
\hline 1 & RW 13 & 2.141 & 2,14 & 1.000 \\
\hline 2 & RW 14 & 658 & 1,77 & 372 \\
\hline \multicolumn{2}{r|}{} \\
\hline
\end{tabular}

Tabel 4.2 Jumlah penduduk RW 14 Kawasan Tamansari 2016 menurut usia

\begin{tabular}{|c|c|c|c|c|c|}
\hline NO & $\begin{array}{c}\text { KELOMPOK } \\
\text { UMUR }\end{array}$ & $\mathbf{L}$ & $\mathbf{P}$ & JUMLAH & $\%$ \\
\hline 1 & $0-4$ & 21 & 11 & 32 & \multirow[b]{3}{*}{21} \\
\hline 2 & $05-9$ & 29 & 28 & 57 & \\
\hline 3 & $10-14$ & 21 & 24 & 45 & \\
\hline 4 & $15-19$ & 23 & 27 & 50 & \multirow{8}{*}{65} \\
\hline 5 & $20-24$ & 18 & 30 & 48 & \\
\hline 6 & $25-29$ & 26 & 29 & 55 & \\
\hline 7 & $30-34$ & 33 & 36 & 69 & \\
\hline 8 & $35-39$ & 30 & 22 & 52 & \\
\hline 9 & $40-44$ & 20 & 25 & 45 & \\
\hline 10 & $45-49$ & 29 & 26 & 55 & \\
\hline 11 & $50-54$ & 19 & 29 & 48 & \\
\hline
\end{tabular}


210 | Sri Hidayati Djoeffan, et al.

\begin{tabular}{|c|c|c|c|c|c|}
\hline 12 & $55-59$ & 13 & 14 & 27 & \\
\hline 13 & $60-64$ & 15 & 10 & 25 & \multirow{2}{*}{14} \\
\hline 14 & $65>$ & 16 & 21 & 37 & 14 \\
\hline
\end{tabular}

Sumber : Hasil Penelitian 201

\subsection{Pendidikan}

Pendidikan masyarakatnya mayoritas pada tingkat SMA, yaitu 48\% di RW13 dan 49\% di RW14. Warga yang berpendidikan perguruan tinggi hanya 16\% di RW14 dan 29\% di RW13, sedangkan yang berpendidikan SMP di masing-masing RW sebanyak $13 \%$. Pendidikan warga yang lulus SD yaitu 9\% di RW13 dan $21 \%$ merupakan warga RW14, sedangkan yang tidak lulus SD masing-masing sebanyak $1 \%$.

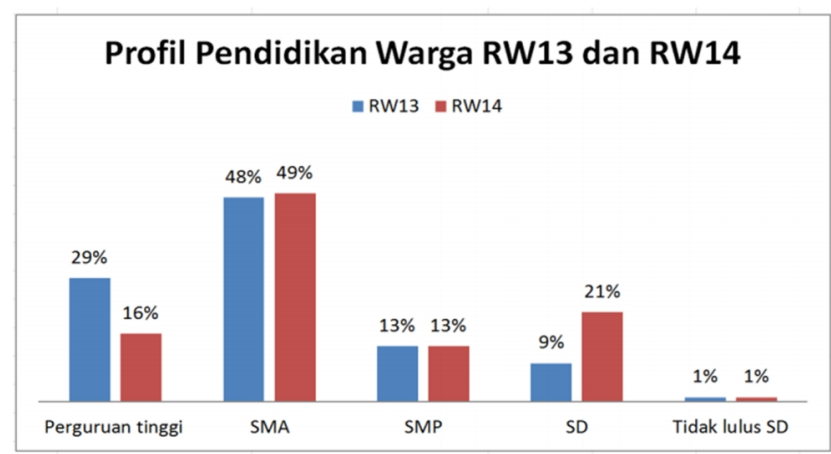

Sumber : Hasil Penelitian 2016

\section{Gambar 4.1 Profil Pendidikan Warga}

\subsection{Pekerjaan dan Lokasi Kerja}

Jenis pekerjaan masyarakat di RW13 mayoritas adalah karyawan swasta yaitu sebanyak 37\%, sebagai PNS atau TNI 4\%, pedagang 32\% buruh $14 \%$ dan lainnya sebanyak 13\%. Sedangkan warga di RW14 sebagai PNS atau TNI sebanyak 3\%, karyawan swasta $19 \%$, pedagang $27 \%$, dan mayoritas memiliki pekerjaan lain-lain sebanyak $51 \%$.

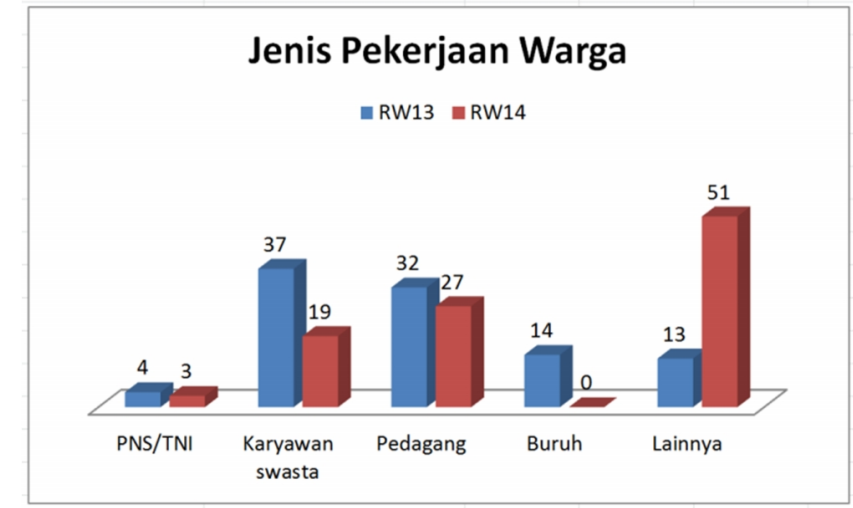

Sumber : Hasil Penelitian 2016

Gambar 4.2 Profil Pekerjaan Warga 
Lokasi kerja warga RW13 dan RW14 mayoritas bekerja di lingkungan RT (Rukun Tangga) mereka sendiri, terutama warga RW14 yang bekerja di lingkungan RT sebanyak $67 \%$, di lingkungan RW (rukun warga) sebanyak 4\% dan di kecamatan sebanyak $12 \%$, serta di lingkungan keluarga sebanyak $7 \%$, sehingga dapat dikatakan 90\% warga RW14 bekerja di lingkungan yang sangat dekat dengan rumah tinggal mereka, hanya 3\% yang bekerja di luar kota. Demikian pula kondisi warga RW13 memiliki profil lokasi kerja yang tidak jauh berbeda dengan kondisi RW14 (selengkapnya dapat dilihat pada Gambar 5.3).

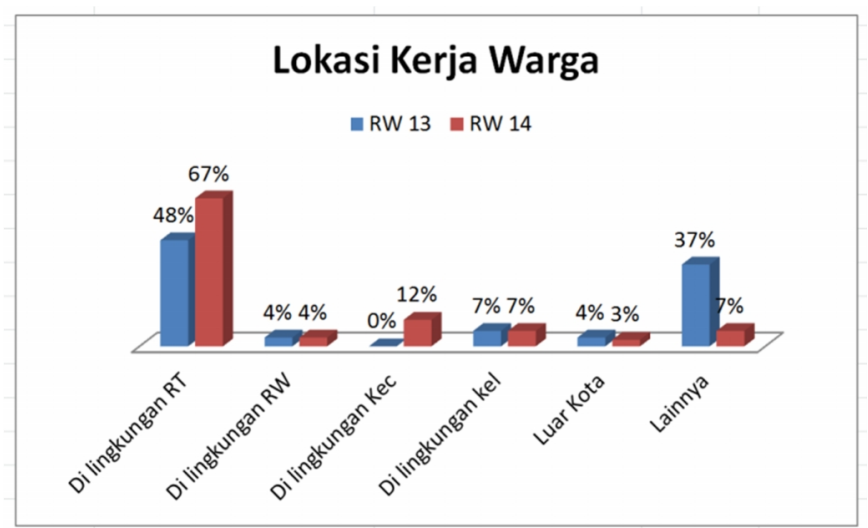

Sumber : Hasil Penelitian 2016

Gambar 4.3 Lokasi Kerja Warga

\subsection{Kondisi Ekonomi Masyarakat}

Mayoritas warga berpenghasilan 2 - 4 juta rupiah per bulan (46\%), penghasilan lebih kecil dari satu jura rupiah (29,50\%), antara satu sampai 2 juta sampai 4 juta rupah $(21,13 \%)$ dan antara 4 sampai 8 juta (10,50\%), Artinya 50,63\% masyarakat berpengahasilan di bawah upah minimum Regional Kota Bandung. Hanya 10\% warga yang memiliki penghasilan antara 4-8 juta per bulan, dan tidak ada warga yang memiliki penghasilan lebih dari 8 juta/bulan. Umumnya kemampuan menabung warga antara Rp. 100.000 sampai Rp. 200.000 per bulan. Ada pula warga yang tidak mempunyai kemampuan menabung yaitu sebanyak $18 \%$.

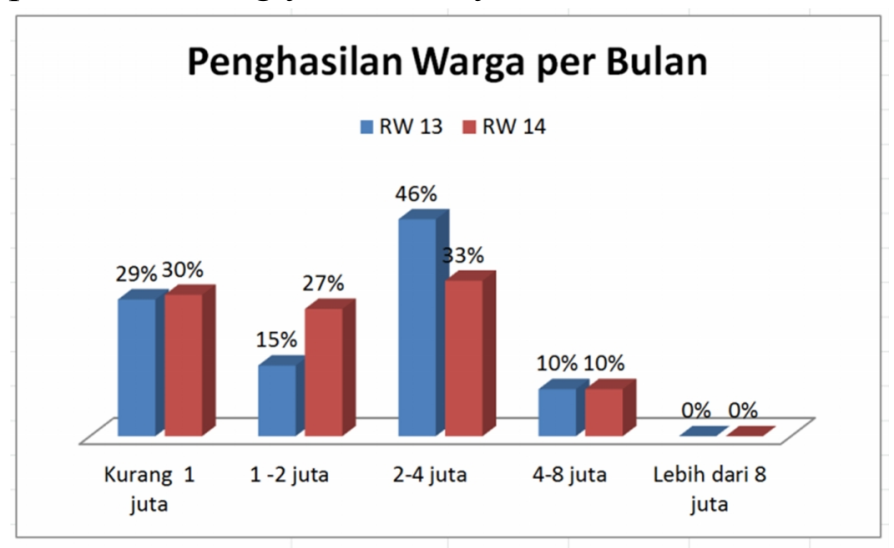

Sumber : Hasil Penelitian 2016

Gambar 4.4 Penghasilan Warga per Bulan 


\subsection{Kondisi Hunian}

Rata2 hunian per rumah mayoritas menunjukan banwa 30\% hunian yang ada berpenghuni 6 sampai 10 orang/rumah, 58\% berpenghuni 3 sampai 6 orang/rumah, $7 \%$ berpenghuni lebih dari 10 orang/rumah dan kurang dari 3 orang/rumah menunjukan $5 \%$. Dapat dipahami penduduk asli berpenghasilan dari menyewakan kamar untuk kos para pelajar dan mahasiswa.

Tabel 4.3 Jumlah Hunian Warga RW 13 dan 14 (Orang / Rumah )

\begin{tabular}{|l|l|c|c|c|c|}
\hline No & $\begin{array}{c}\text { Wilayah } \\
\text { Adminitrasi }\end{array}$ & $<3$ orang & $3-6$ orang & $6-10$ orang & $>10$ orang \\
\hline 1 & RW 13 & 5,00 & 58,00 & 30,00 & 7,00 \\
\hline 2 & RW 14 & 7,7 & 60,60 & 25,13 & 7,7 \\
\hline & Rata-rata & 6,35 & 59,3 & 27,55 & 7,35 \\
\hline
\end{tabular}

Sumber : Hasil Penelitian 2016

\subsection{Fungsi Rumah Tinggal}

Fungsi rumah di lingkungan RW13 dan RW14 umumnya digunakan sebagai fungsi komersial dan rumah tinggal, terutama di lingkungan RW14 81\% rumah tinggal digunakan sebagai rumah kos mahasiswa atau warung/toko. Sedangkan di RW 13 umumnya difungsikan sebagai rumah tinggal (84\%), dan untuk warung/toko sebanyak $16 \%$.

\subsection{Kondisi Bangunan dan Lingkungan}

Kondisi bangunan di kawasan penelitian hampir seluruhnya bangunan permanen, yaitu sebanyak $91,5 \%$ sedangkan bangunan semi permanen hanya sebanyak 8,5\%. Luas bangunan warga mayoritas di atas $120 \mathrm{~m} 2$, yaitu $74 \%$ di RW 13 dan 59\% di RW14, dengan luas lahan yang sempit maka umumnya bangunan rumah tinggal merupakan bangunan bertingkat. Banyaknya bangunan bertingkat di RW 13 hal ini sesuai dengan bahwa umumnya fungsi rumah tinggal di RW13 adalah sebagai rumah kos untuk mahasiswa dan pelajar.

Tabel 4.4 Kondisi Bangunan Rumah Tinggal Warga

\begin{tabular}{|l|l|c|c|}
\hline \multicolumn{1}{|c|}{ No } & \multicolumn{1}{|c|}{ Wilayah Administrasi } & Permanen (\%) & SemiPermanen (\%) \\
\hline 1 & RW 13 & 93,00 & 7,00 \\
\hline 2 & RW 14 & 90,00 & 10,00 \\
\hline & Rata-rata & 91,50 & 8,5 \\
\hline
\end{tabular}

Sumber : Hasil Penelitian 2016 


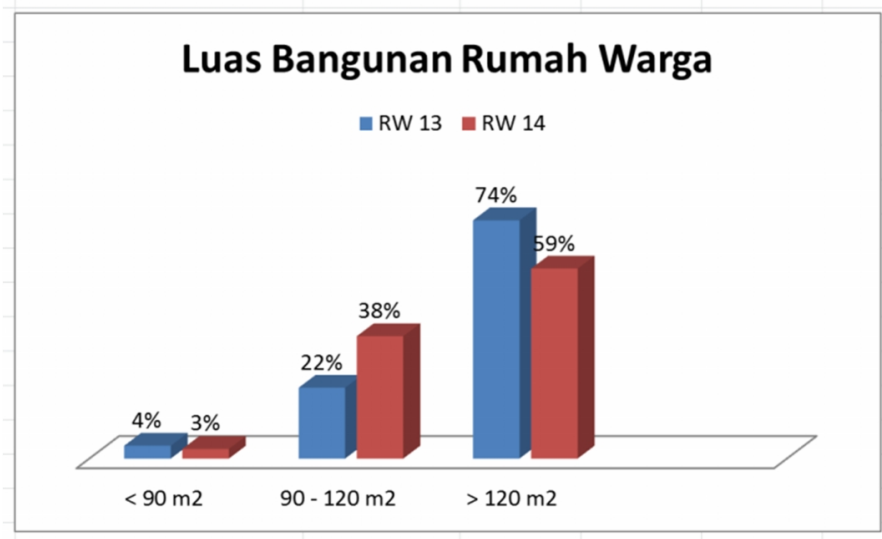

Sumber : Hasil Penelitian 2016

Gambar 4.5 Luas Bangunan Rumah Warga

Secara umum di kawasan ini masyarakat sudah terbiasa hidup di bangunan bertingkat yang ditunjukan oleh $71 \%$ penduduk tinggal dibangunan bertingkat antara 2 sampai 3 lantai dan 19\% menepati bangunan berlantai satu. Banyaknya bangunan tinggi di ruang yang sangat sempit mengakibatkan matahari tidak dapat masuk dengan baik, sehingga menyebabkan udara di sekitar perumahan menjadi lembab. Hal ini terlihat banyaknya lumut yang menempel di bawah dinding rumah.

Kualitas lingkungan di RW 13 agak sedikit lebih kumuh jika dibandingkan dengan kualitas lingkungan di RW 14. Selain karena tidak adanya jarak antar rumah warga, juga dikarenakan kurangnya pepohonan maupun tanaman-tanaman disekitar lingkungan RW 13 terlebih bagi warga yang tinggal di bantaran Sungai Cikapundung. Walaupun kondisi lingkungan agak lembab namun pada umumnya udara di sekitar rumah masyarakat tidak berbau (77\%) dan hanya 23\% yang lingkungan udaranya berbau kurang nyaman. Sempitnya lahan di area perumahan menyebabkan hampir $100 \%$ warga hanya bisa menanam tumbuhan dalam pot bunga. Hanya sedikit sekali yang menanam tumbuhan langsung di tanah pekarangan. Bila ada sedikit lahan kosong dipinggiran tembok, maka warga memanfaatkannya untuk menanam tumbuhan. Jenis tumbuhan yang paling sesuai untuk lingkungan yang agak lembab adalah jenis Sansivera atau lidah mertua. Sansivera ini juga dapat berfungsi menyerap polutan udara, sehingga bisa memberikan sedikit kesegaran di lokasi yang sangat sempit seperti di RW13 dan RW14. 


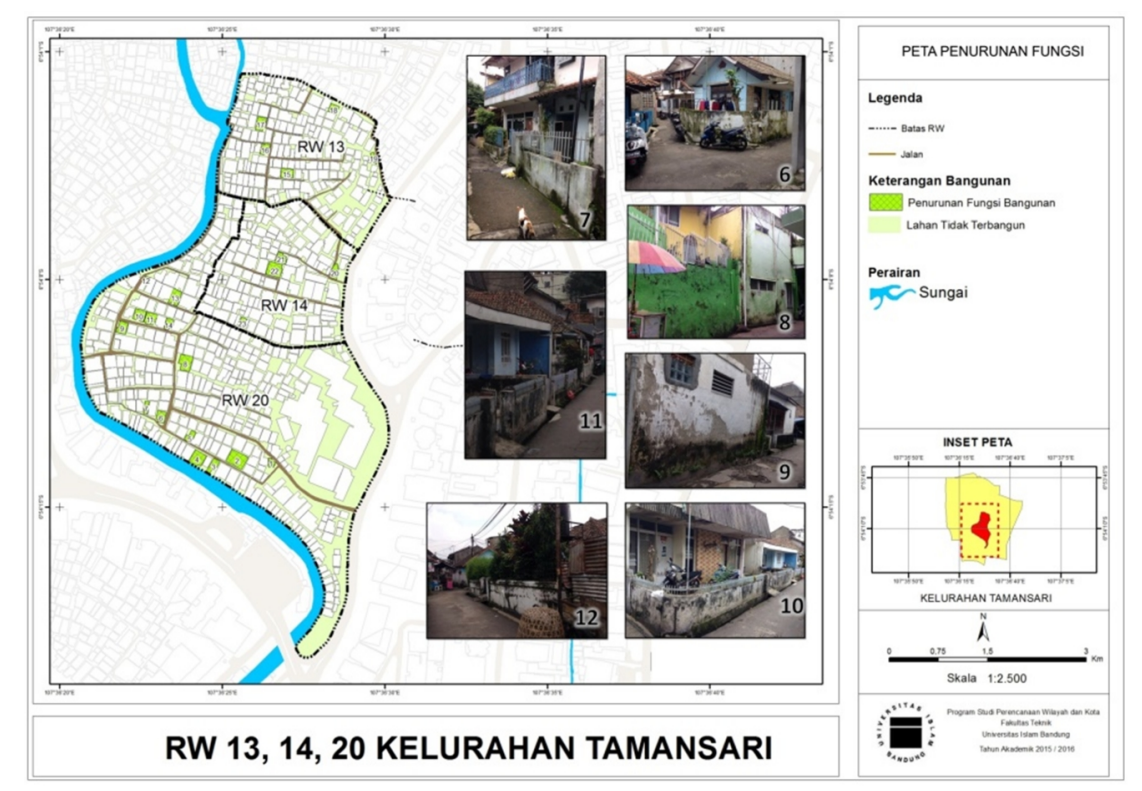

\subsection{Hidrologi.}

\subsubsection{Sumber Air Bersih}

Pada umumnya warga RW 13 dan RW 14 menggunakan sumur bor sebagai sumber air bersih untuk memenuhi kebutuhan air rumah tangga, seperti mandi dan cuci, sedangkan air PDAM yang dialirkan melalui pipa distribusi digunakan sebagai sumber air minum dan memasak. Warga RW 13 yang memiliki sumur bor sebanyak 63\% sedangakan warga RW 14 sebanyak 53\%. Warga RW 13 yang menggunakan PDAM sebanyak 37\% dan warga RW 14 sebanyak 47\%. Saat ini tidak ada lagi warga yang menggunakan sumur gali sebagai sumber air bersih maupun mata air. Warga yang menggunakan air sumur bor sebagai subtitusi air PDAM, melakukan penyaringan air sumur bor untuk menghilangkan kekeruhan dan bau sebelum digunakan untuk mandi dan mencuci. Bila ditinjau dari kualitas air bersih yang digunakan warga, maka sebanyak $80 \%$ menjawab kualitas air sumur bor yang digunakan adalah baik, dan jernih, dan $20 \%$ warga yang menjawab kualitas air sumur bornya keruh dan berbau, sehingga sebelum digunakan air akan difilter atau disaring terlebih dahulu.

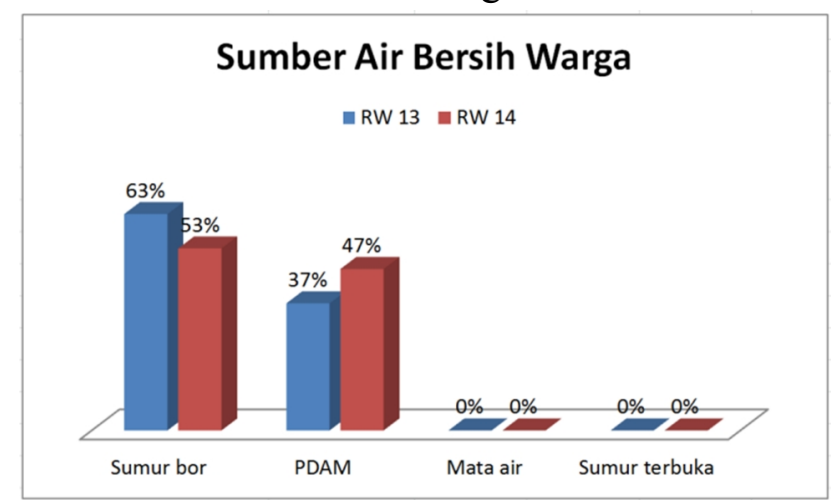

Sumber: hasil penelitian, 2016

Gambar 4.6 Sumber Air Bersih Warga 


\subsubsection{Supply Air Bersih}

Volume supply air bersih yang digunakan masyarakat umumnya cukup untuk memenuhi kebutuhan sehari-hari hanya 4\% warga di RW14 yang kekurangan supply air bersih dan 37\% di RW13. Sehingga mayoritas warga mendapatkan kecukupan air bersih untuk digunakan sehari-hari.

\subsubsection{Kualitas Air Bersih dan Air Sungai Cikapundung}

Bila dilihat dari hasil uji di laboratorium kualitas air sumur bor Warga 13 memang kurang baik dan dinyatakam tidak layak digunakan sebagai air minum (lihat Tabel 4.5), karena air sumur bor memiliki tingkat kekeruhan yang sangat tinggi, yaitu 71,3 NTU sedangkan ambang batas yang diijinkan sebagai air minum (Permenkes Nomor 907 tahun 2002) hanya 5 NTU. Parameter lain yang melebihi baku mutu adalah warna dan konsentrasi ion Fe 3+ (besi), ion mangan (Mn 2+). Sedangkan kualitas sumur bor warga RW 14 yang diuji di laboratorium menunjukkan kualitas yang lebih baik dari pada RW 13. Seluruh parameter berada di bawah ambang batas yang dipersyaratkan dalam Peraturan Menteri Kesehatan Nomor 907 Tahun 2002 sebagai persyaratan air minum. Demikian pula dengan kualitas air sumur bor warga RW 20 seluruh parameter kualitas air berada dibawah ambang batas yang diijinkan sebagai persyaratan air minum. Untuk membandingkan kualitas air sumur bor warga dengan air PDAM, dilakukan pula pengujian kualitas air PDAM di laboratorium. Terlihat bahwa kualitas air PDAM memang lebih baik daripada kualitas air sumur bor warga. Air PDAM memiliki nilai daya hantar listrik yang rendah dibandingkan dengan air sumur bor warga yaitu 117 uS/cm sedangkan sumur warga memiliki daya hantar listrik antara 300-605 uS/cm. demikian pula untuk tingkat kesadahan, air PDAM memiliki nilai yang paling rendah dbandingkan kesadahan air sumur bor. Tingkat kesadahan ini akan mempengaruhi kualitas air ketika digunakan untk mencuci, air yang memiliki tingkat kesadahan yang tinggi akan sulit membuat sabun berbusa. Selain air sumur dan PDAM, telah dilakukan pula pengujian kualitas air Sungai Cikapundung di laboratorium untuk mengetahui tingkat pencemaran yang terjadi di air Sungai Cikapundung.

Standar uji yang digunakan untuk mengukur kualitas air Sungai Cikapundung adalah Peraturan Pemerintah RI Nomor 82 Tahun 2001 tentang Pengelolaan Kualitas Air dan Pengendalian Pencemaran Air untuk air kelas satu. Yang dimaksud dengan kelas air adalah peringkat kualitas air yang dinilai layak untuk dimanfaatkan bagi peruntukan tertentu, maka air kelas satu adalah air yang peruntukannya dapat digunakan untuk air baku air minum, dan atau peruntukan lain yang mempersyaratkan mutu air yang sama dengan kegunaan tersebut. Bila dilihat dari hasil uji laboratorium. Air sungai Cikapundung dapat digunakan sebagai air baku air minum dengan terlebih dahulu dilakukan pemrosesan untuk menghilangkan kekeruhan, logam-logam berat, seperti kalsium, magnesium, besi, mangan, kalium, natrium. Serta menurunkn tingkat kesadahan air dan menurunkan nitrit, ammonia, dan bikarbonat. Seperti juga diketahui bahwa salah satu sumber air yang digunakan oleh PDAM adalah air Sungai Cikapundung. Dalam penelitian ini, air Sungai Cikapundung tidak diuji parameter biologi yang menunjukan tingkat pencemaran, seperti e-coli, BOD dan COD, dll. 
Tabel 4.5

\begin{tabular}{|c|c|c|c|c|c|c|}
\hline \multicolumn{7}{|c|}{ HASIL ANALISA KIMIA / FISIKA CONTOH AIR SUMUR WARGA DAN PDAM } \\
\hline Parameter & Unit & \begin{tabular}{|l|} 
Maksimum diperbolehkan \\
907/Menkes/SK/VII/2002 \\
\end{tabular} & RW 13 & RW 14 & $\mathrm{RW} 20$ & PDAM \\
\hline Kekeruhan & NTU & 5 & 71.3 & 1.1 & 0.5 & 1.9 \\
\hline Warna & TCU & 15 & 20 & 5 & 0 & 0 \\
\hline Bau & - & Tidak berbau & tb & tb & tb & tb \\
\hline Rasa & - & Tidak berasa & th & tb & tb & tb \\
\hline Daya Hantar Listrik & us/cm & - & 605 & 328 & 336 & 117 \\
\hline $\mathrm{pH}$ & Unit pH & $6.5-8.5$ & 6.66 & 6.61 & 6.6 & 6.52 \\
\hline Kesadahan & $\mathrm{mg} / \mathrm{L} \mathrm{CaCO} 3$ & 500 & 188.5 & 100.4 & 121.9 & 43.7 \\
\hline Ca2+(Kalsium) & $\mathrm{mg} / \mathrm{L}$ & - & 43.6 & 19 & 3.5 & 8.6 \\
\hline Mg2+ (Magnesium) & $\mathrm{mg} / \mathrm{L}$ & - & 19.1 & 12.7 & 27.2 & 5.3 \\
\hline \begin{tabular}{|l} 
Fe3+ (Besi) \\
\end{tabular} & $\mathrm{mg} / \mathrm{L}$ & 0.3 & 6.5 & 0.02 & 0.1 & 0 \\
\hline Mn2+ (Mangan) & $\mathrm{mg} / \mathrm{L}$ & 0.1 & 0.3 & 0.1 & 0 & 0 \\
\hline K+ (Kalium) & $\mathrm{mg} / \mathrm{L}$ & - & 6.4 & 0 & 0.1 & 0 \\
\hline $\mathrm{Na}+$ (Natrium) & $\mathrm{mg} / \mathrm{L}$ & 200 & 42.9 & 18 & 28.9 & 5.7 \\
\hline Li+ (Litium) & $\mathrm{mg} / \mathrm{L}$ & - & 0 & 0 & 0 & 0 \\
\hline $\mathrm{NH} 4+$ (Amonium) & $\mathrm{mg} / \mathrm{L}$ & 1.5 & 7.8 & 0 & 0 & 0 \\
\hline CO3 $=$ (Karbonat) & $\mathrm{mg} / \mathrm{L}$ & - & 0 & 0 & 0 & 0 \\
\hline HCO3- (Bikarbonat) & $\mathrm{mg} / \mathrm{L}$ & - & 292.5 & 107 & 129.7 & 37.9 \\
\hline Cl-(Klorida) & $\mathrm{mg} / \mathrm{L}$ & 250 & 45.3 & 31.4 & 25.2 & 15.3 \\
\hline SO4= (Sulfat) & $\mathrm{mg} / \mathrm{L}$ & 250 & 6.8 & $\frac{3.4}{12.8}$ & 12.1 & 2.1 \\
\hline NO2-(Nirit) & $\mathrm{mg} / \mathrm{L}$ & 3 & 0.2 & 0.7 & 0 & 0 \\
\hline NO3-(Nitrat) & $\mathrm{mg} / \mathrm{L}$ & 50 & 0 & 5.2 & 23.5 & 0 \\
\hline Zat Padat Terlarut & $\mathrm{mg} / \mathrm{L}$ & 1000 & 404 & $\frac{2.20}{220}$ & 226 & 80 \\
\hline Sumber: Hasil penelitia & & & & & & \\
\hline
\end{tabular}

Tabel 4.6

\begin{tabular}{|c|c|c|c|}
\hline \multicolumn{4}{|c|}{ HASIL ANALISA KIMIA / FISIKA CONTOH AIR SUNGAI CIKAPUNDUNG } \\
\hline \multirow{2}{*}{ Parameter } & \multirow{2}{*}{ Unit $\mathrm{pH}$} & \multirow{2}{*}{$\begin{array}{c}\text { Maksimum diperbolehkan } \\
\text { (PP/No.82 Tahun 2001/Kelas 1) }\end{array}$} & \multirow{2}{*}{ Sungai Cikapundung } \\
\hline & & & \\
\hline Kekeruhan & NTU & - & 182 \\
\hline Warna & TCU & - & 15 \\
\hline Bau & - & - & tb \\
\hline Rasa & - & - & tb \\
\hline Daya Hantar Listrik & $\mathrm{uS} / \mathrm{cm}$ & - & 156 \\
\hline $\mathrm{pH}$ & Unit pH & $6.0-9.0$ & 6.44 \\
\hline Kesadahan & $\mathrm{mg} / \mathrm{L} \mathrm{CaCO} 3$ & - & 63.3 \\
\hline $\mathrm{Ca} 2+$ (Kalsium) & $\mathrm{mg} / \mathrm{L}$ & - & 12.8 \\
\hline Mg2+ (Magnesium) & $\mathrm{mg} / \mathrm{L}$ & - & 7.5 \\
\hline Fe3+ (Besi) & $\mathrm{mg} / \mathrm{L}$ & 0.3 & 3.2 \\
\hline Mn2+ (Mangan) & $\mathrm{mg} / \mathrm{L}$ & 0.1 & 0.2 \\
\hline K+ (Kalium) & $\mathrm{mg} / \mathrm{L}$ & - & 0.1 \\
\hline $\mathrm{Na}+$ (Natrium) & $\mathrm{mg} / \mathrm{L}$ & - & 7.6 \\
\hline Li+ (Litium) & $\mathrm{mg} / \mathrm{L}$ & - & 0 \\
\hline $\mathrm{NH} 4+$ (Amonium) & $\mathrm{mg} / \mathrm{L}$ & 0.5 & 0.7 \\
\hline $\mathrm{CO} 3=$ (Karbonat) & $\mathrm{mg} / \mathrm{L}$ & - & 0 \\
\hline HCO3- (Bikarbonat) & $\mathrm{mg} / \mathrm{L}$ & - & 76.7 \\
\hline Cl- (Klorida) & $\mathrm{mg} / \mathrm{L}$ & 600 & 11.9 \\
\hline SO4= (Sulfat) & $\mathrm{mg} / \mathrm{L}$ & 400 & 7.3 \\
\hline NO2-(Nirit) & $\mathrm{mg} / \mathrm{L}$ & 0.06 & 0.18 \\
\hline NO3- (Nitrat) & $\mathrm{mg} / \mathrm{L}$ & 10 & 0 \\
\hline Zat Padat Terlarut & $\mathrm{mg} / \mathrm{L}$ & 1000 & 106 \\
\hline Sumber: Hasil penelitiar & & & \\
\hline
\end{tabular}

\subsubsection{Sistem Drainase Air}

Salah satu permasalahan lingkungan yang menonjol di lingkungan Kelurahan Tamansari adalah permasalahan saluran terbuka (drainase). Pada umumnya drainase tidak terpelihara dengan baik sehingga meningkatkan kelembaban lingkungan dan menimbulkan banjir ketika hujan, terutama di RW 13 dimana kondisi saluran yang dinyatakan baik oleh warga RW13 hanya 40\% sedangkan jaringan lama dan yang rusak sebanyak 60\%. Untuk kondisi saluran terbuka di lingkungan RW14 jauh lebih baik dibandingkan dengan RW13, dimana warga di RW14 mengatakan bahwa saluran terbuka di lingkungan mereka dalam kondisi baik sebanyak $83 \%$, tidak ada yang rusak. Yang ada hanya saluran bekas jaringan lama yang dipertahankan warga dan dalam kondisi baik. 

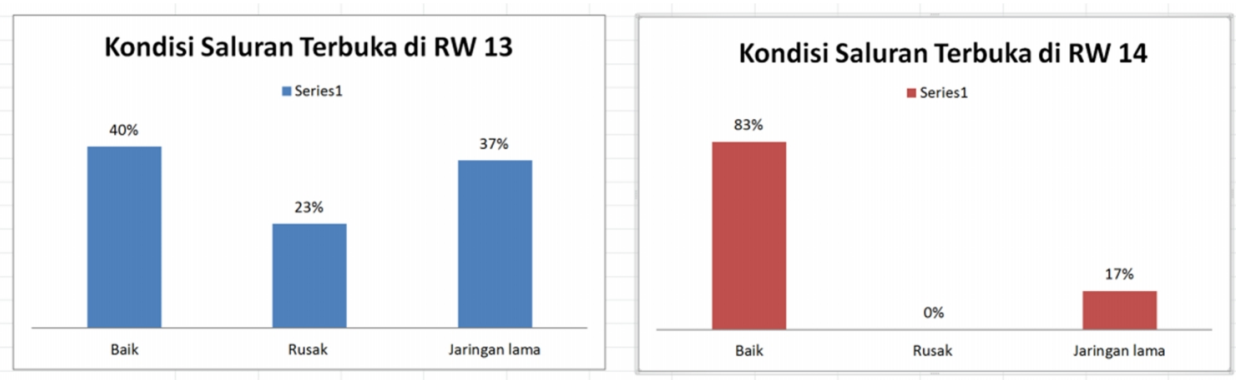

Sumber: hasil penelitian, 2016

\section{Gambar 4.7 Kondisi Saluran Terbuka}

Penyebab terjadinya genangan air di RW13 dan RW14 terlihat pada gambar berikut. Genangan air yang terjadi di RW13 umumnya disebabkan karena saluran yang mampet karena timbunan sampah yang menghambat di saluran (57\%) sehingga walaupun tidak ada hujan tetap terjadi genangan air yang berasal dari buangan air rumah tangga, ditambah dengan saluran biopori yang didapatkan dari subsidi pemerintah yang hanya memiliki kedalaman $<10$ meter sehingga menyebabkan rembesan air hujan tidak berfungsi secara maksimal. Sedangkan di RW14 saluran yang tersumbat sampah hanya sebesar 25\% karena kondisi saluran terbuka di RW14 dalam kondisi baik. Genangan air yang ada di RW14 umumnya disebabkan karena adanya hujan (75\%) sehingga kondisi lingkungan cukup kering ketika tidak ada hujan. Di kedua RW tersebut tidak pernah terjadi banjir akibat adanya luapan air Sungai Cikapundung.
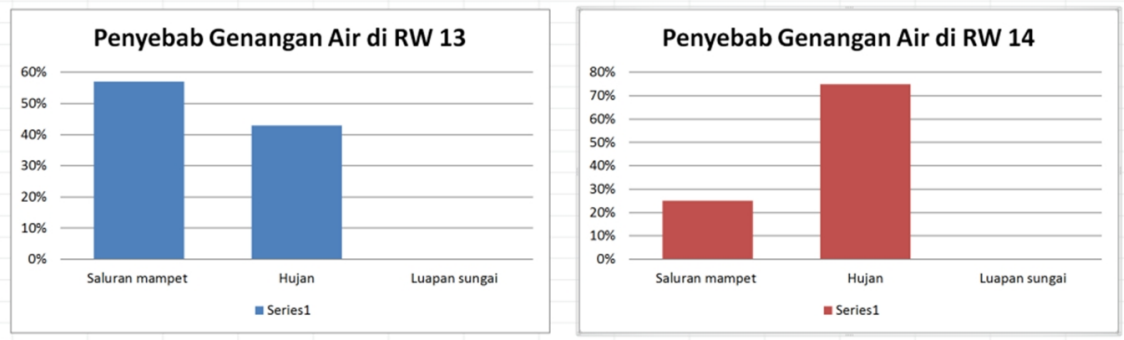

Sumber: hasil penelitian, 2016

\section{Gambar 4.8 Penyebab Terjadinya Genangan Air}

Warga RW13 dan RW14, umumnya, mengatakan bahwa frekuensi terjadinya genangan air di lingkungan rumah mereka adalah tidak dapat diprediksi, tidak dapat dipastikan terjadinya setiap 6 bulan atau 1 tahun sekali.

\subsection{Kondisi Sanitasi Lingkungan}

Sanitasi adalah perilaku disengaja dalam pembudayaan hidup bersih dengan maksud mencegah manusia bersentuhan langsung dengan kotoran dan bahan buangan bahaya lainnya dengan harapan usaha ini akan menjaga dan meningkatkan kesehatan manusia. Semua warga di RW13 dan RW14 memiliki sarana sanitasi di dalam rumah, seperti MCK (mandi cuci dan kakus), sehingga tidak ada lagi yang melakukan MCK di Sungai Cikapundung. Namun air buangan dari mandi, cuci dan kakus di rumah warga 
umumnya dilepas secara langsung ke Sungai Cikapundung karena hampir semua rumah dikedua RW tersebut tidak memiliki septic tank. Hal ini merupakan salah satu penyebab pencemaran lingkungan yang sangat signifikan, mengingat jumlah penduduk RW13 dan RW14 berjumlah kurang lebih 2.000 orang.

\subsection{Tempat Pembuangan Sampah}

Warga RW13 dan RW14 umumnya memiliki bak sampah sehingga tidak ada lagi yang membuang sampah ke Sungai Cikapundung ataupun membakar sampah. Sampah akan dikumpulkan oleh petugas kebersihan kemudian membuangnya ke tempat pembuangan sementara (TPS) di jalan Tamansari.

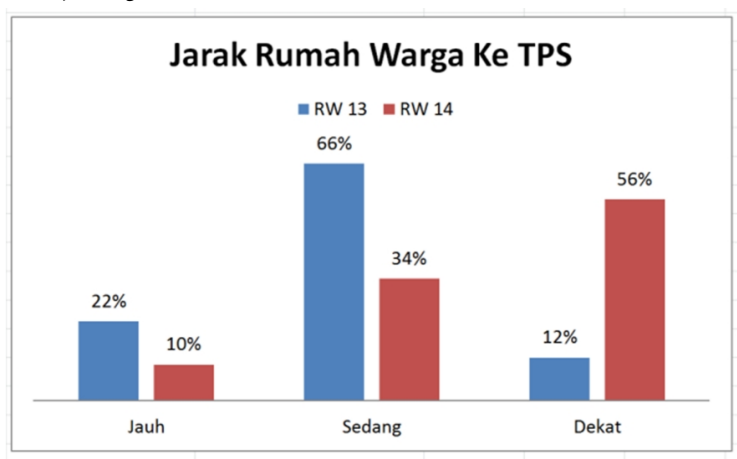

Sumber: hasil penelitian, 2016

\section{Gambar 4.9 Jarak Rumah Warga ke TPS}

Jarak buang ke TPS mempengaruhi kebersihan lingkungan rumah warga. Warga di RW14 sebanyak 56\% mengatakan bahwa jarak dari rumah mereka dekat ke TPS sedangkan warga RW13 hanya 12\% yang mengatakan dekat ke TPS. Warga RW13 yang berpendapat bahwa rumah mereka jauh dari TPS sebanyak 22\% sedangkan warga RW14 yang mengatakan jauh hanya 10\%. Warga RW13 mengatakan jarak ke TPS adalah sedang sebanyak $66 \%$ sedangkan warga RW14 yang menyatakan jarak ke TPS adalah sedang, sebanyak 34\%. Selan itu TPS yang ada di atas sebenarnya kurang memadai dari segi kuantitas, dikarenakan TPS tersebut digunakan oleh 2 RW yakni RW 13 dan RW 20 sehingga sampah di TPS tersebut selalu melebihi kapasitas (meluber ke jalan).

\subsection{Jalan}

Jenis perkerasan jalan yang ada di lingkungan RW 13 ini sebagian besar menggunakan beton (semen) yang sebagian besar pula dalam kondisi rusak. Penggunaan beton semen (74\%) dan aspal (26\%) dengan kondisi perkerasan baik (15\%), rusak (48\%) dan kerusakan sedang (37\%). Sedangkan jenis perkerasan yang ada di lingkungan RW 14 sebagian besar menggunakan aspal dan sebagian kecil menggunakan beton dengan kualitas sedang hingga baik. RW 14 yang dijadikan sebagai RW 14 percontohan mengharuskan warga untuk bergotong royong memperbaiki jalan dan lingkungan sekitar. Selain dari pada itu RW 14 pun banyak mendapatkan dana atau sumbangan dari pemda untuk perbaikan jalan. 


\subsection{Fasilitas Umum}

Fasilitas umum adalah fasilitas-fasilitas yang dapat digunakan oleh masyarakat, ataupun tempat berkumpul masyarakat, seperti sarana ibadah, sekolah dan sarana olah raga. Di RW 13 dan RW14 tidak ada sarana olah raga, baik lapangan bulu tangkis, tenis meja dll. Sedangkan fasilitas pendidikan yang ada di Kelurahan Tamansari hanya Paud dan Sekolah Dasar, dimana sesungguhnya sarana pendidikan ini berada di RW 20. Sarana pendidikan Paud melayani 27\% warga dan SD melayani 88\% warga Kelurahan Tamansari.

\subsection{Organisasi Masyarakat}

Masyarakat di RW 13 yang melakukan kegiatan pengajian (63\%) dan kerja bakti sosial (37\%), dan warga RW14 yang melakukan pengajian sebanyak 34\%, kerjabakti $36 \%$ dan karang taruna melibatkan $30 \%$ warganya. Artinya masyarakat bersifat religious dan sebagian masih memiliki budaya gotong royong yang bersifat positif dan jiwa empati yang masih terpelihara. Terlihat warga RW14 lebih aktif dalam kegiatan sosial masyarakat, termasuk karang taruna untuk para pemudanya. Hal ini berdampak positif pada lingkungan di RW14 yang jauh lebih bersih, teratur dan lebih hijau dibandingkan dengan lingkungan di RW13.

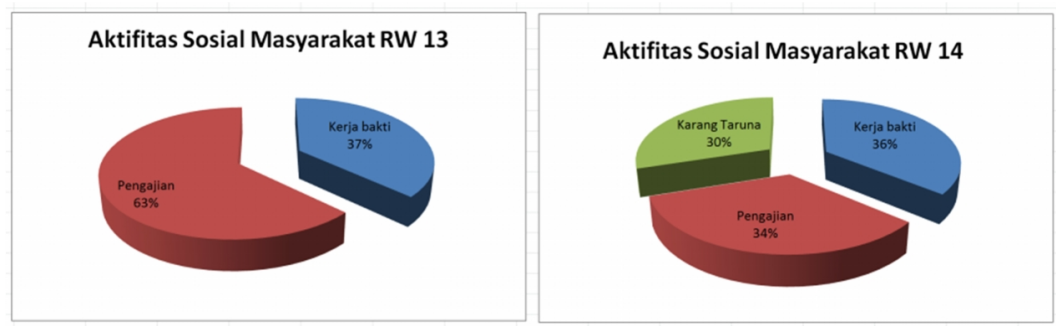

Sumber: hasil penelitian, 2016

Gambar 4.10 Aktifitas Sosial Mayarakat

\subsection{Perbaikan Lingkungan}

Kelurahan Tamansari merupakan salah satu kawasan yang menjadi target pemerintah Kota Bandung untuk diperbaiki lingkungannya. Pemerintah kota terus melakukan penyuluhan perlunya hidup sehat, menjaga kebersihan dan keindahan lingkungan serta mengurangi pencemaran Sungai Cikapundung. Sebanyak 70\% warga RW14 pernah mendapatkan informasi tentang perbaikan lingkungan dari pemerintah Kota Bandung, dan hanya 56\% warga RW13 yang menerima informasi tersebut. Hal ini berdampak positif pada lingkungan di RW14 yang jauh lebih bersih, teratur dan lebih hijau dibandingkan dengan lingkungan di RW13.

Informasi tentang perbaikan lingkungan yang diterima oleh warga RW14 berasal dari aparat atau pejabat sebanyak 90\% sedangkan warga RW13 memperoleh informasi ini dari LSM (Lembaga Swadaya Masyarakat) sebanyak 90\%. Perbaikan sepadan sungai yang telah dilakukan oleh pemerintah kota sangat memberikan nilai positif bagi masyarakat oleh karena itu, seluruh warga setuju untuk memperbaiki sepadan sungai 
sehingga ruang terbuka sepadan sungai bisa dimanfaatkan oleh warga untuk berbagai kegiatan, seperti jalan kaki, bersepeda bahkan jalan pintas.

Perbaikan lingkungan yang diharapkan oleh warga RW13 dan RW14 yang utama adalah perbaikan drainase, kemudian disusul dengan pengadaan TPS di RW13 dan perbaikan MCK di RW 14. Warga juga mengharapkan adanya tempat berobat yang murah, dekat dan dapat di akses kapan saja. Karena selama ini warga berobat ke puskesmas yang jaraknya cukup jauh dari rumah. Selain itu, warga juga mengharapkan adanya perbaikan lingkungan sekolah yang ada agar anak-anak dapat belajar dengan aman dan nyaman.

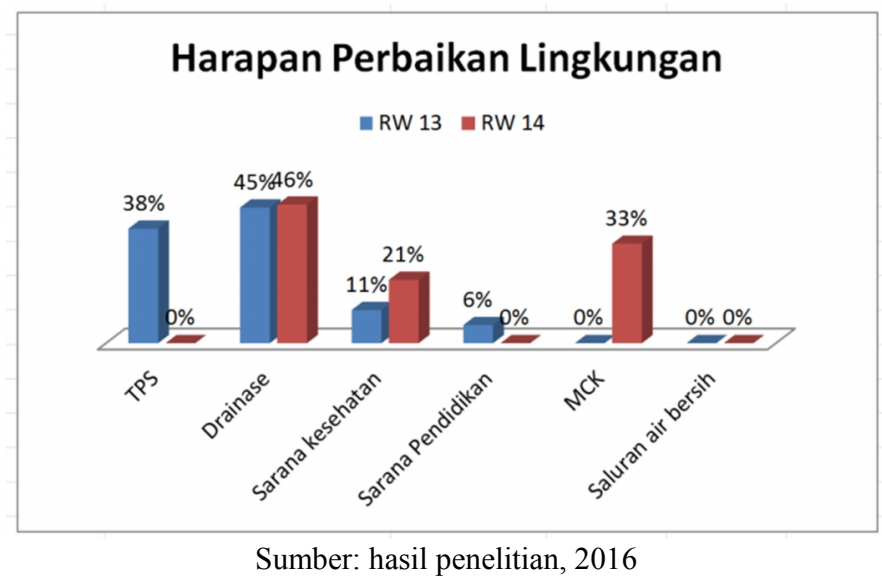

Gambar 4.11 Perbaikan Lingkungan yang Diharapan Warga

\subsection{Harapan Masyarakat RW 13 dan RW14}

Harapan masyarakat warga RW 13 dan RW 14 yang diasumsikan dapat mewakili harapan masyarakat Kelurahan Tamansari terhadap keberadaan Unisba adalah sebagai berikut:

1. Sebanyak $24 \%$ masyarakat membutuhkan area parkir terutama untuk roda empat (mobil) mengingat sempitnya lahan di sekitar perumahan, maka masyarakat berharap Unisba memiliki area parkir untuk mahasiswanya sehingga di jalan sekitar Tamansari dapat digunakan oleh masyarakat untuk area parkir mereka.

2. Lapangan pekerjaan dari kampus untuk warga Kelurahan Tamansari, sebanyak 9.5\%. Sebagai sebuah institusi pendidikan Unisba dapat dikatakan berpunggungan dengan masyarakat Kelurahan Tamansari maka diharapkan salah satu program tanggung jawab sosial Unisba adalah memprioritaskan warga Kelurahan Tamansari mendapat pekerjaan di lingkungan Kampus Unisba.

3. Sebanyak $9.5 \%$ masyarakat berharap Unisba memiliki program pemberian beasiswa bagi anak kurang mampu dan berprestasi.

4. Sebanyak 9.5\% masyarakat Kelurahan Tamansari juga berharap Unisba memberi bantuan untuk warga kurang mampu.

5. Masyarakat RW13 sebanyak $19 \%$ berharap ada perbaikan jalan sedangkan warga di RW14 tidak membutuhkan perbaikan jalan sama sekali. 
6. Selain di atas, harapan masyarakat Kelurahan Tamansari lainnya adalah adanya area bermain anak, lapangan olah raga, penerangan jalan, dan lain-lain. Selengkapnya dapat dilihat pada Tabel berikut.

Tabel 4.7 Harapan Masyarakat Terhadap Keberadaan Unisba

\begin{tabular}{|c|l|c|c|}
\hline No. & Harapan Warga & RW 13 & RW 14 \\
\hline 1 & Penghijauan & $5 \%$ & - \\
\hline 2 & Ambulance & $6 \%$ & $5 \%$ \\
\hline 3 & Penataan taman & $1 \%$ & - \\
\hline 4 & Perbaikan jalan & $19 \%$ & - \\
\hline 5 & Penerangan jalan & $8 \%$ & $3 \%$ \\
\hline 6 & Bantuan warga tidak mampu & $10 \%$ & $9 \%$ \\
\hline & Tempat penyuluhan ibu dan & & \\
7 & anak & $3 \%$ & $7 \%$ \\
\hline 8 & Tempat pengajian anak & $1 \%$ & $5 \%$ \\
\hline 9 & Lapangan pekerjaan & $5 \%$ & $14 \%$ \\
\hline 10 & Beasiswa kuliah di Unisba & $6 \%$ & $9 \%$ \\
\hline 11 & Area bermain & $8 \%$ & $10 \%$ \\
\hline 12 & Lapangan olah raga & $7 \%$ & $8 \%$ \\
\hline 13 & Lahan terbuka hijau & $3 \%$ & - \\
\hline 14 & Lahan parkir & $18 \%$ & $30 \%$ \\
\hline & \multicolumn{2}{|c}{} \\
\hline
\end{tabular}

\section{Kesimpulan}

1. Kawasan Penelitian merupakan suatu lingkungan yang berada di bawah standar kesehatan. Terbukti dari terjadinya berbagai degradasi fungsional, lingkungan dan visual.

Degradasi fungsional digambarkan ddengan adanya pelanggaran aturan sempadan sungai.

Degradasi lingkungan seperti kualitas air yang buruk, udara yang lembab, kepadatan penduduk yang tinggi, miskinnya ruang terbuka dan minimnya vegetasi serta tanah yang basah (wet land), genangan air yang memercepat memburuknya bangunan.

$>$ Degradasi visual seperti pemandangan yang kurang nyaman baik dari warna, bau.

2. Masyarakat warga Tamansari yang diwakili oleh warga RW13 dan RW 14, mengharapkan adanya program tanggung jawab sosial Unisba, seperti:

> Unisba menyediakan lahan parkir khusus untuk mahasiswanya

$>$ Lapangan pekerjaan dari kampus untuk warga Kelurahan Tamansari.

$>$ Pemberian beasiswa bagi anak kurang mampu dan berprestasi.

> Bantuan untuk warga kurang mampu

$>$ Harapan lainnya seperti adanya area bermain anak, lapangan olah raga, dan penerangan jalan 


\section{Saran}

Saran meliputi Rencana tindak yang akan dijabarkan dalam rencana jangka panjang, menengah dan jangka pendek yang berisi program peneltian dan pengabdian pada masyarakat secara umum. Diharapkan akan saran ini akan membuka berbagai peluang penelitian da pengambdian dari berbagai Fakultas yang ada dalam lingkungan Unisba dan kerjasama dengan berbagai instansi pemerintah maupun swasta.

\subsection{Rencana jangka Panjang (25 tahun) dan rencana jangka menengah} (10 tahun) yang secara umum banyak melibatkan Institusi luar Unisba.

\begin{tabular}{|c|c|c|c|}
\hline \multicolumn{2}{|c|}{ Jangka Panjang } & \multicolumn{2}{|l|}{ Jangka Menengah } \\
\hline Program & Pelaksanaan & Program & Pelaksanaan \\
\hline \multirow[t]{4}{*}{$\begin{array}{l}\text { Peremajaan } \\
\text { kota }\end{array}$} & $\begin{array}{l}\text { Pemeruntah } r \text { Kodya, } \\
\text { Kemenpera PU dan } \\
\text { departemen Sektoral. }\end{array}$ & \begin{tabular}{ll}
\multicolumn{2}{l}{ Pembangunan } \\
Septik Tank \\
Komunal
\end{tabular} & $\begin{array}{lr}\text { Pemeruntah } & \text { Kodya, } \\
\text { Kemenpera PU } & \text { dan } \\
\text { departemen Sektoral. } & \end{array}$ \\
\hline & & $\begin{array}{l}\text { Perbaikan } \\
\text { Drainase }\end{array}$ & $\begin{array}{l}\text { Pemerintah Daerah \& } \\
\text { Departemen Sektoral }\end{array}$ \\
\hline & & $\begin{array}{l}\text { Unisba membuat } \\
\text { sarana olah Raga } \\
\text { yang dapat } \\
\text { dimanfaatkan } \\
\text { bersama } \\
\text { masyarakat }\end{array}$ & UNISBA \\
\hline & & $\begin{array}{l}\text { Pembangunan } \\
\text { sarana Parkir }\end{array}$ & UNISBA \\
\hline
\end{tabular}

\subsection{Usulan Program Penelitian dan Pengabdian Unisba secara menyeluruh yang meliputi Penelitian, dan Pengabdian kepada masyarakat serta Kesalehan Sosial.}

\begin{tabular}{|l|l|l|l|l|l|}
\hline Penelitian & Pelaksana & $\begin{array}{l}\text { Pengabdian } \\
\text { pada } \\
\text { masyarakat }\end{array}$ & Pelaksana & $\begin{array}{l}\text { Kesalehan } \\
\text { Sosial dan } \\
\text { Proyek } \\
\text { Pembangunan }\end{array}$ & Pelaksana \\
\hline $\begin{array}{l}\text { Kesehatan } \\
\text { masayarakat } \\
\text { kawasan RW } \\
\begin{array}{l}13 \text { dan 14 } \\
\text { Tamansari }\end{array}\end{array}$ & $\begin{array}{l}\text { Fak. } \\
\text { Kedokeran } \\
\text { UNISBA }\end{array}$ & $\begin{array}{l}\text { Sosialisasi } \\
\text { Hidup Sehat } \\
\text { dan 3R }\end{array}$ & Unisba & $\begin{array}{l}\text { Bantuan } \\
\text { Penyediaan } \\
\text { lapangan kerja }\end{array}$ & UNISBA \\
\hline
\end{tabular}




\begin{tabular}{|c|c|c|c|c|c|}
\hline Bandung & & & & & \\
\hline $\begin{array}{l}\text { Pembinaan } \\
\text { UMKM }\end{array}$ & Fak,Ekonomi & $\begin{array}{l}\text { PKM : } \\
\text { Pengeccatan } \\
\text { bangunan anti } \\
\text { lumut. }\end{array}$ & CSR & $\begin{array}{l}\text { Subsidi } \\
\text { Pelayanan } \\
\text { Kesehatan }\end{array}$ & UNISBA \\
\hline $\begin{array}{l}\text { Kualitas } \\
\text { Sumberdaya } \\
\text { Manusia } \\
\text { masayarakat } \\
\text { kawasan RW } \\
13 \text { dan } 14 \\
\text { Tamansari } \\
\text { Bandung }\end{array}$ & Fak,Psikologi & $\begin{array}{l}\text { PKM : } \\
\text { Penyuluhan } \\
\text { Vertical } \\
\text { garden. }\end{array}$ & $\begin{array}{ll}\text { CSR } & \& \\
\text { UNISBA } & \end{array}$ & $\begin{array}{l}\text { Pemberian } \\
\text { /santunan } \\
\text { Beasiswa. }\end{array}$ & UNISBA \\
\hline \begin{tabular}{l}
\multicolumn{2}{l}{ Peremajaan } \\
Kawasan RW \\
13 dan RW 14 \\
Taman sari \\
Bandung
\end{tabular} & $\begin{array}{l}\text { Fakultas } \\
\text { Teknik }\end{array}$ & $\begin{array}{l}\text { PKM : } \\
\text { Penyuluhan } \\
\text { pembangunan } \\
\text { closet }\end{array}$ & $\begin{array}{l}\text { CSR } \\
\text { UNISBA }\end{array}$ & & \\
\hline
\end{tabular}

\section{Ucapan Terimakasih}

Terimakasih kepada LPPM Unisba yang telah mendanai penelitian ini.

\section{Daftar pustaka}

Abe, 2001, Perencanaan Daerah Memperkuat prakarsa Rakyat alam Otonomi daerah, Jogjakata, Lappera Pustaka Utama eJournal Ilmu Pemerintahan, 2013, 1 (2): 612 625 ISSN 0000-0000, ejournal.ip.fisip-unmul.ac.id (C) Copyright 2013).

Bryant, C. And Whyte.LG, 1989, Manajemen Pembangunan, Jakarta LP3ES.

Delivery, 2004, Pendekatan Partisipasi masyarakat dalam pengelolaan Sumber Daya Alam, www.delivery.com. Diunduh 04 juli 2004.

IRENE, S, 2011, Desenralisasi dan Pertisipasi masyarakat, Jogyakarta, Pustaka Pelajar Nazir.

Sutanto, 2008, Partisipasi masyarakat dlam pelestarian sungai Cikapundung, UPI, Bandung.

Zubaidi, 2007, Wacana Pembangunan Alternatife, Yogyakarta: AR-RUZ Media.

Undang-Undang No. 32 Tahun 2004 tentang Pemerintah daerah.

Peraturan Pemerintah Nomor 82 Tahun 2001 Tentang Pengelolaan Kualitas Air dan Pengendalian Pencemaran Air.

Peraturan Menteri Kesehatan Nomor 907 Tahun 2002 Tentang Syarat-Syarat dan Pengawasan Kualitas Air Minum. 